\title{
TRPV1-Like Immunoreactivity in the Human Locus $K$, a Distinct Subregion of the Cuneate Nucleus
}

\author{
Marina Del Fiacco ${ }^{1}$ (D), Maria Pina Serra ${ }^{1}$ (i), Marianna Boi ${ }^{1}$, Laura Poddighe ${ }^{1}$, \\ Roberto Demontis ${ }^{2}$, Antonio Carai ${ }^{2}$ and Marina Quartu ${ }^{1, *}$ \\ 1 Department of Biomedical Sciences, University of Cagliari, Cittadella Universitaria di Monserrato, \\ 09042 Monserrato (CA), Italy; marina.delfiacco@gmail.com (M.D.F.); mpserra@unica.it (M.P.S.); \\ marianna.boi@unica.it (M.B.); laura.poddighe@gmail.com (L.P.) \\ 2 Department of Medical Sciences and Public Health, University of Cagliari, Cittadella Universitaria di \\ Monserrato, 09042 Monserrato (CA), Italy; demrob@unica.it (R.D.); acarai@medicina.unica.it (A.C.) \\ * Correspondence: quartu@unica.it; Tel.: +39-070-675-4084
}

Received: 29 April 2018; Accepted: 5 July 2018; Published: 8 July 2018

\begin{abstract}
The presence of transient receptor potential vanilloid type-1 receptor (TRPV1)-like immunoreactivity (LI), in the form of nerve fibres and terminals, is shown in a set of discrete gray matter subregions placed in the territory of the human cuneate nucleus. We showed previously that those subregions share neurochemical and structural features with the protopathic nuclei and, after the ancient name of our town, collectively call them Locus Karalis, and briefly Locus K. TRPV1-LI in the Locus $\mathrm{K}$ is codistributed, though not perfectly overlapped, with that of the neuropeptides calcitonin gene-related peptide and substance $\mathrm{P}$, the topography of the elements immunoreactive to the three markers, in relation to each other, reflecting that previously described in the caudal spinal trigeminal nucleus. Myelin stainings show that myelinated fibres, abundant in the cuneate, gracile and trigeminal magnocellular nuclei, are scarce in the Locus $\mathrm{K}$ as in the trigeminal substantia gelatinosa. Morphometric analysis shows that cell size and density of Locus K neurons are consistent with those of the trigeminal substantia gelatinosa and significantly different from those of the magnocellular trigeminal, solitary and dorsal column nuclei. We propose that Locus $\mathrm{K}$ is a special component of the human dorsal column nuclei. Its functional role remains to be determined, but TRPV1 appears to play a part in it.
\end{abstract}

Keywords: human medulla oblongata; cuneate nucleus; dorsal column nuclei; TRPV1; calcitonin gene-related peptide; substance $P$

\section{Introduction}

The transient receptor potential vanilloid type-1 receptor (TRPV1) is a polymodal ion channel expressed in primary sensory neurons, critically involved in the perception of mechanical and thermal stimuli as well as in pain modulation, and in allodynia and hyperalgesia in neuropathic pain [1-7]. Temperature (over $42{ }^{\circ} \mathrm{C}$ ), low extracellular $\mathrm{pH}$ and capsaicin represent TRPV1 activators often used in experimental studies. To date, TRPV1 is viewed as a molecular integrator of different stimuli in the peripheral polymodal nociceptors; thus, it is activated by noxious heat, acidic and basic $\mathrm{pH}$, voltage, endogenous lipid-derived compounds, and a variety of substances, among which the agonist resiniferatoxin is the best known $[1,2,4,8-11]$. In rodents, TRPV1 is expressed by a subset of peripheral sensory neurons involved in pain sensation [12-22]. Available studies on human tissue show the occurrence of TRPV1 in neurons of dorsal root ganglia (DRG) $[15,23-28]$ and trigeminal ganglion (TG) $[29,30]$, and their central and peripheral endings [25,31-33]. TRPV1, in addition to Calcitonin Gene-Related Peptide (CGRP) and Substance P (SP), is localized in primary sensory neurons and, 
in particular, in those of small and medium size, with poorly myelinated or unmyelinated small calibre fibres, responsible for the reception of nociceptive protopathic stimuli. It has been shown that, in primary sensory neurons, TRPV1 activation triggers the release of CGRP and SP [11,33-37], typical markers of the capsaicin-sensitive sensory neurons [8]. The neuropeptides in turn activate their effector cell receptors, leading to neurogenic inflammation and sensitization of nociceptors $[8,11]$. The aberrant activation of TRPV1 has been implicated in different neuropathological conditions including inflammation [38-43], neuropathic pain [26,27,31,43], visceral pain [40,41,43-45], nerve injury [43,46,47] and migraine [33]. In humans, the local injection of capsaicin has been shown to cause sensitization of the cutaneous afferents [48-50], release of CGRP from peripheral nerve endings [11,51,52] and pain in the deep somatic tissues [53-56].

Classically, the dorsal column nuclear complex consists of the larger cuneate, gracile and external cuneate nuclei, and of the smaller medial and lateral pericuneate nuclei, nucleus $\mathrm{Z}$ and nucleus $X$ of Pompeiano and Brodal [57]. For the most part, they receive large myelinated primary afferent fibres conveying somatic epicritic, kinesthetic and proprioceptive sensation from the trunk and limbs, and relay to the thalamus and cerebellum. Several substances have been identified as synaptic neurotransmitters in the dorsal column nuclei. Thus, glutamate and glycine and gamma-aminobutyric acid act as excitatory and inhibitory neurotransmitters [58-66], and other molecules, such as adenosine triphosphate, acetylcholine, and monoamines, may also function as transmitters and/or modulators [58,67-69]. As a general rule, neuropeptide immunoreactive elements are less abundant in dorsal column nuclei than in regions that relay protopathic and nociceptive stimuli, namely the spinal dorsal horn and the spinal trigeminal and solitary nuclei, both in humans [70-75] and in laboratory animals [76-91]. Recently, we have formally defined additional distinctive subdivisions of the human dorsal column nuclei, evident from prenatal to old life [92]. Extending early observations on the presence of gray matter areas that are strongly immunoreactive to SP in the territory of the human cuneate nucleus and adjacent fascicle [70,71], we have shown that the cuneate nucleus fields rich in SP also host neural structures immunoreactive to the neuropeptides CGRP, methionine- and leucine-enkephalin, peptide histidine-isoleucine, somatostatin and galanin, the trophin glial cell line-derived neurotrophic factor, and the neuroplasticity proteins polysialylated neural cell adhesion molecule and growth-associated protein-43 [92] and references therein. Moreover, the topographical distribution of the structures immunoreactive to all those markers in relation to each other clearly showed that the neurochemistry of those cuneate nucleus gray matter fields, at variance with the remaining nuclear territory, was strikingly similar to that of the spinal cord dorsal horn and the spinal nucleus of the trigeminal nerve [70,71,92-97]. As a tribute to the place where M.D.F. first observed and described those discrete cuneate nucleus subregions, after the ancient name of our town, Cagliari, we collectively call them Locus Karalis and briefly Locus K $[98,99]$.

With the aim of further describing the capsaicin-sensitive component of the human nervous system, here we show that the Locus K, identified by its immunoreactivity to SP and CGRP, also contains TRPV1-like immunoreactivity (LI) in specimens from prenatal and neonatal life to adult age. Furthermore, we show that the cyto- and myeloarchitecture of the Locus K also harmonize with those of the protopathic and nociceptive sensory nuclei.

\section{Materials and Methods}

\subsection{Tissue Sampling}

Specimens of medulla oblongata were obtained at autopsy from subjects with no signs of neuropathology, at age ranging 21 gestation weeks to 88 years (Table 1). The sampling and handling of human specimens conformed to the guidelines of the local Ethics Committee of the National Health System and complied with the principles enunciated in the Declaration of Helsinki. R.D. and A.C. collected the human tissues and R.D. was the only one to have access to identifying information about the autopsied subjects. The used specimens had been stored as part of the standardized procedure 
for autopsy samples at the section of Forensic Medicine of the Department of Public Health, Clinical and Molecular Medicine. The Ethics Committee formally stated that the present study complied with the ethical principles and does not need approval because all the used specimens were processed anonymously (Report No. 9, 15/07/2015). Fixation in 4\%, freshly prepared phosphate-buffered formaldehyde, $\mathrm{pH} 7.3$, for $4-6 \mathrm{~h}$ at $4{ }^{\circ} \mathrm{C}$, was followed by overnight rinsing in $0.1 \mathrm{M}$ phosphate buffer (PB), $\mathrm{pH} 7.3$, containing $5-20 \%$ sucrose.

Table 1. List of specimens.

\begin{tabular}{ccccc}
\hline Case & Age & Sex & Primary Cause of Death & $\begin{array}{c}\text { Post-Mortem } \\
\text { Hours }\end{array}$ \\
\hline 1 & Fetus 21 w.g. & F & Cardiorespiratory failure & 29 \\
2 & Pre-term newborn 6 d (25 w.g.) & F & Pneumonitis & 25 \\
3 & Pre-term newborn 1 d (34 w.g.) & M & Cardiorespiratory failure & 29 \\
4 & Pre-term newborn (38 w.g.) & M & Cardiorespiratory failure & 38 \\
5 & Full-term newborn (40 w.g.) & M & Cardiorespiratory failure & 28 \\
6 & Full-term newborn 1 d & M & Cardiorespiratory failure & 24 \\
7 & Full-term newborn 2 d & F & Persistence of fetal circulation & 38 \\
8 & Full-term newborn 7 d & F & Cardiorespiratory failure & 27 \\
9 & Adult 44 y & M & Stabbing & 40 \\
10 & Adult 53 y & F & Cardiorespiratory failure & 31 \\
11 & Adult 56 y & F & Cardiomyopathy & 34 \\
12 & Adult 71 y & M & Renal failure & 25 \\
\hline
\end{tabular}

F, female; d, days; h, hours; M, male; y, years; w.g., weeks of gestation (calculated from the 1st day of the latest menstrual cycle).

\subsection{Immunohistochemistry and Histology}

Adjacent transverse slices of the medulla oblongata were cut with a cryostat at 10-14 or $30 \mu \mathrm{m}$ and collected in series on chrome alum-gelatin coated slides. The avidin-biotin-peroxidase complex (ABC) immunostaining technique was used. Slides were treated with $0.1 \%$ phenylhydrazine (Sigma Aldrich, St Louis, MO, USA) in phosphate buffered saline (PBS) containing $0.2 \%$ Triton X-100 (PBS/T) to block the endogenous peroxidase activity, and successively with $20 \%$ of normal goat serum (Vector Labs Inc., Burlingame, CA, USA) to minimize non-specific staining. Rabbit polyclonal antibodies against TRPV1 (Thermo Scientific, Waltham, MA, USA), diluted 1:500, and against CGRP (Chemicon, Temecula, CA, USA), diluted 1:1000, and a guinea-pig polyclonal antibody against SP (AbCam, Cambridge, UK), diluted 1:1200, were used as primary antibody. Biotin-conjugated goat anti-rabbit and anti-guinea-pig sera (Vector), both diluted 1:400, were used as secondary antiserum. The immunoreaction was revealed with $30 \mathrm{~min}$ of incubation with the ABC (BioSpa Div. Milan, Italy), diluted 1:250, and followed by incubation with a solution of $0.1 \mathrm{M}$ phosphate buffer (PB), $\mathrm{pH} 7.3$, containing $0.05 \% 3$, 3'-diaminobenzidine (Sigma Aldrich, St Louis, MO, USA), 0.04\% nickel ammonium sulfate and 0.01\% hydrogen peroxide. All antisera and ABC were diluted in PBS/T. The specificity of the TRPV1 antibody has been validated by Western blot analysis on protein samples of human pre-term and adult TG and caudal medulla oblongata, and reported in a previous work [30]. Negative control preparations were obtained either by incubating tissue sections with the diluted primary antibody preabsorbed with $10 \mathrm{mM}$ of the respective peptide for $24 \mathrm{~h}$ at $4{ }^{\circ} \mathrm{C}$ or by omitting the primary antibody. Cresyl violet, Black-Gold II staining kit (Biosensis, Thebarton, Australia) and/or Klüver-Barrera techniques were used as Nissl and myelin stainings. Observations and photographs were made with a photomicroscope Olympus BX61 (Hamburg, Germany), and with a slide scanner Nanozoomer 2.0-RS (Hamamatsu).

\subsection{Morphometric Analysis}

Morphometric analysis was performed on cuneate nucleus, gracile nucleus, external cuneate nucleus, Locus K, caudal spinal trigeminal nucleus substantia gelatinosa and magnocellular part, and solitary nucleus. Cell size analysis was performed on digital images captured with a $20 \times$ 
objective magnification. Cell mean diameters were automatically measured by Leica Application Suite Advanced Fluorescence (LAS AF) Software; statistical parameters (mean, minimum, maximum, S.D.) and histograms of the cell sizes were obtained by the Statistica 7 software (Version 7.0.61.0; StatSoft Inc., Palo Alto, CA, USA). Cell density (number of cells $/ \mathrm{mm}^{2}$ ) was measured on digital images captured with a $10 \times$ objective magnification; statistical analysis was performed with One-way analysis of variance (ANOVA) and the Tukey's post-hoc test by means of the software GraphPad Prism 6 for Windows (GraphPad Software, La Jolla, San Diego, CA, USA)

\section{Results}

In the human caudal medulla oblongata of all examined specimens, from fetal and neonatal age (Figure 1a,b and Figure 2a) to adult life (Figure 3a,b), at levels between the pyramidal decussation and the obex, the territory of the cuneate nucleus contains distinct areas of gray matter that include TRPV1 strongly positive networks of varicose filaments and dot-like structures, interpreted as nerve fibres and terminals. By contrast, the remaining territory of the cuneate nucleus hosts scarce immunoreactivity. No evidence of immunoreactive cell bodies was found. Compared to the outcome in newborn tissue, the density of TRPV1-like immunoreactive structures appears reduced in adult specimens. No gender differences were observed. Immunostaining for CGRP and SP in adjacent sections allows for ascertaining that the TRPV1-LI is localized to the Locus K (Figures 1a-d and 2a,b). However, though codistributed, the immunoreactivity for the receptor and the neuropeptides do not strictly overlap. In fact, though present in the superficial dorsal edge of the gray area, the bulk of TRPV1-LI, compared with the CGRP- and SP-LI, occupies a deeper zone of the Locus K (Figures 1a-d and 2a,b). This is congruent with the previously described localization of the three markers in the substantia gelatinosa of the caudal spinal trigeminal nucleus [27]. As described for the neuropeptides [67,68,89], TRPV1-like immunoreactive fibres, either isolated or in thin bundles, are detectable within the cuneate fascicle (Figure 3c). No positive labelling is detectable at levels rostral to the obex. Alternate sections immunolabelled for TRPV1 and the neuropeptides, and histochemically stained for myelin (Figures 1 and 2) effectively contribute to demonstrate the topographical localization of the TRPV1-LI of the Locus $\mathrm{K}$ and show its myeloarchitectural organization. In particular, analysis of myelin stained sections shows that the cuneate nucleus subregions with strong immunoreactivity to TRPV1 and the two neuropeptides contain rare myelinated fibres, whereas numerous stained fibres can be seen running across the territory of the main cuneate nucleus (Figures 1-3). As previously described for the other markers, at certain levels, two distinct components of the Locus $\mathrm{K}$, both containing TRPV1-LI, are detectable in the horizontal plane (Figure 2). The two regions are both located along the dorsal boundary of the cuneate nucleus, one in a dorsal and/or medial position, and the other one lateral to the cuneate nucleus and medial to the dorsomedial end of the caudal spinal trigeminal nucleus substantia gelatinosa (Figure 2). The medially located region may show a triangular, oval or arched profile, whereas the lateral one is round-shaped and the immunoreactivity is mostly confined to its crescent-shaped dorsal border (Figure 2). The histochemical stainings show that myelinated fibres, abundant in the cuneate nucleus, gracile nucleus, and caudal spinal trigeminal nucleus magnocellular part, conversely are scarce in both the Locus $\mathrm{K}$ and caudal spinal trigeminal nucleus substantia gelatinosa (Figure 1c,d, Figures 2c and 3a,b). 


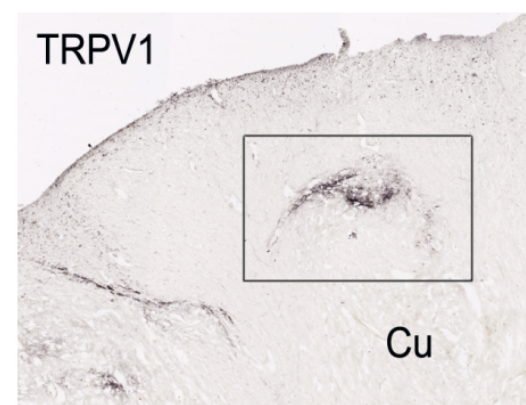

a

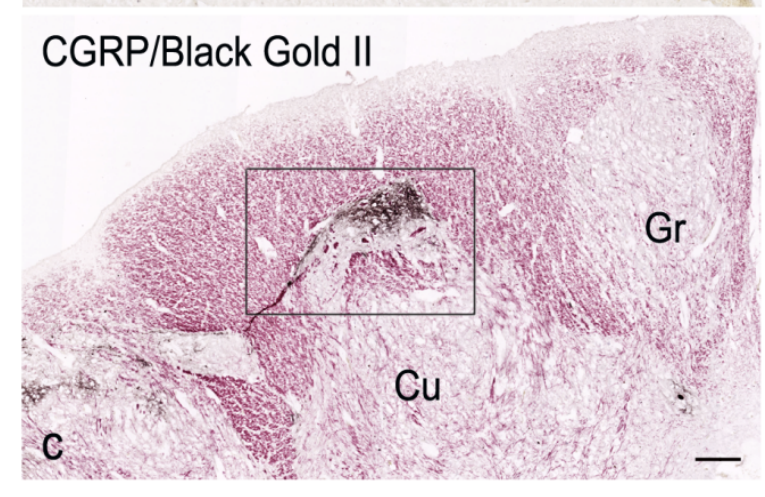

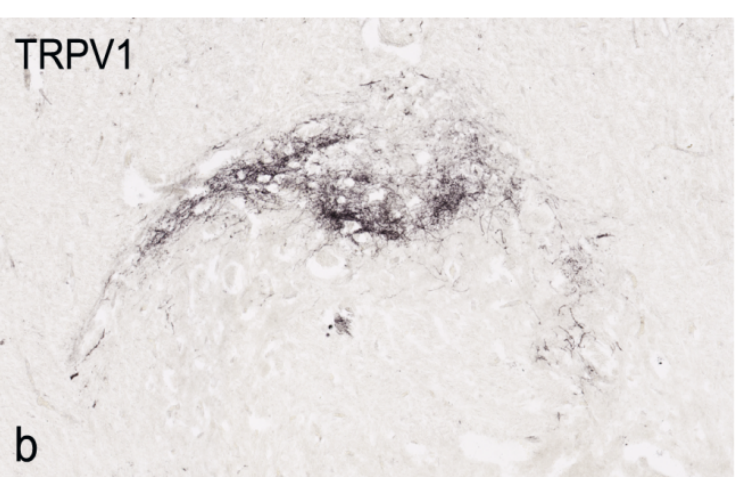

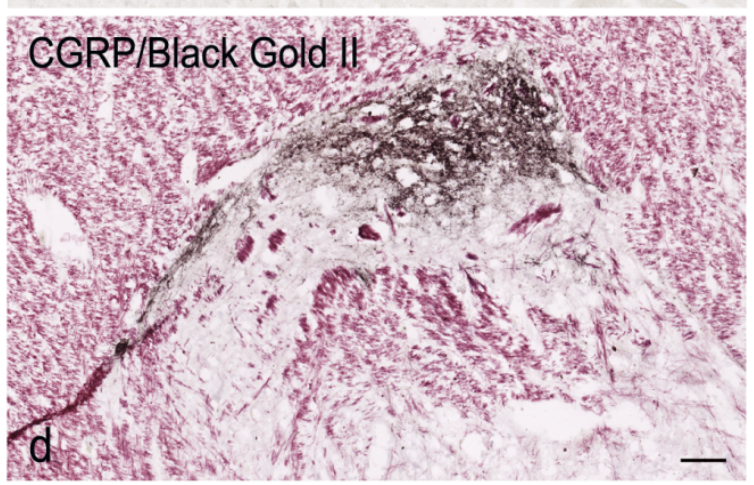

Figure 1. Full-term newborn, case 6. Left side dorsal quadrant in two consecutive sections of the caudal medulla oblongata immunostained for TRPV1 $(\mathbf{a}, \mathbf{b})$ and for CGRP followed by myelin Black Gold II counterstaining (c,d). Strongly TRPV1- and CGRP-like immunoreactive areas, along the dorsal border of the cuneate nucleus $(\mathrm{Cu})$, are located in the Locus $\mathrm{K}$ (box in $(\mathbf{a}, \mathbf{c})$ ) and are shown at higher magnification in $(\mathbf{b}, \mathbf{d})$, respectively. Gr, gracile nucleus. Scale bar: $(\mathbf{a})=(\mathbf{c}): 250 \mu \mathrm{m} ;(\mathbf{b})=(\mathbf{d}): 50 \mu \mathrm{m}$.

Nissl staining performed on adult tissue sections (Figure 4) indicates that, in the LK, the cells are smaller and more closely packed (Figure 4g,h and Figure 5) than in the cuneate nucleus (Figure 4e,f and Figure 5), the histological aspect of the Locus K appearing rather similar to that of the caudal spinal trigeminal nucleus substantia gelatinosa (Figure 4i,j and Figure 5). The obvious tissue structure differences are proved by the analysis of cell size (histograms in Figure 4) and density (Figure 5). In the Locus $\mathrm{K}$, as in the trigeminal substantia gelatinosa, the measured neurons show mean cell diameters between 5 and $18 \mu \mathrm{m}$ (mean 8.55 and $8.68 \mu \mathrm{m}$, respectively), whereas, in the magnocellular part of the caudal spinal trigeminal nucleus, the mean diameters range 5 to $35 \mu \mathrm{m}$ (mean $11.7 \mu \mathrm{m}$ ) and in the solitary nucleus 5 to $26 \mu \mathrm{m}$ (mean $11.4 \mu \mathrm{m}$ ). In dorsal column nuclei, namely cuneate, external cuneate and gracile nuclei, the cell size is definitely larger, the mean cell diameter ranging 5 to $32 \mu \mathrm{m}$ (mean $15 \mu \mathrm{m}$ ) in the cuneate and gracile nuclei, and 13 to $38 \mu \mathrm{m}$ (mean $22 \mu \mathrm{m}$ ) in the external cuneate nucleus. As for the cell density (Figure 5), the mean value is $872.37 / \mathrm{mm}^{2}$ in Locus $\mathrm{K}, 579.63 / \mathrm{mm}^{2}$ in the substantia gelatinosa of caudal spinal trigeminal nucleus, $257.7 / \mathrm{mm}^{2}$ in the magnocellular part of caudal spinal trigeminal nucleus, $323.09 / \mathrm{mm}^{2}$ in the solitary nucleus, and between 125 and $159 / \mathrm{mm}^{2}$ in the dorsal column nuclei (cuneate, external cuneate and gracile nuclei). One-way ANOVA showed that scored differences in density are statistically significant $(p<0.0001)$; single $p$-values adjusted for multiple comparisons among the seven examined nuclear regions are reported in Table 2. 

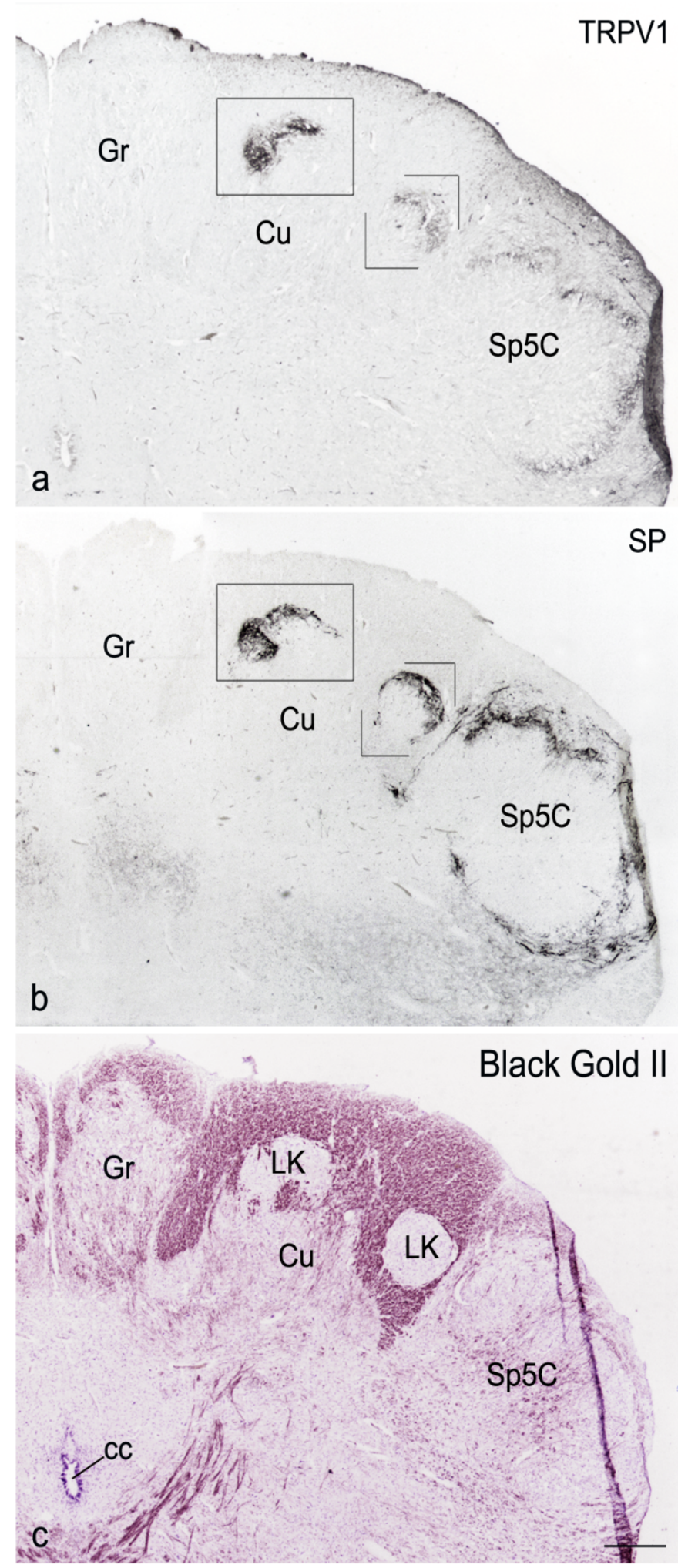

Figure 2. Full-term newborn, case 6. (a-c): right dorsal quadrant of three consecutive sections of the caudal medulla oblongata immunostained for TRPV1 (a) and SP (b), and stained for myelin with Black Gold II (c). TRPV1-LI (boxes in (a)) and SP-LI (boxes in (b)) are codistributed in a parallel way in the Locus K (LK) and in the spinal trigeminal nucleus (Sp5C) substantia gelatinosa. cc, central canal; Cu, cuneate nucleus; Gr, gracile nucleus. Scale bar: $(\mathbf{a}, \mathbf{b})=(\mathbf{c}) 250 \mu \mathrm{m}$. 

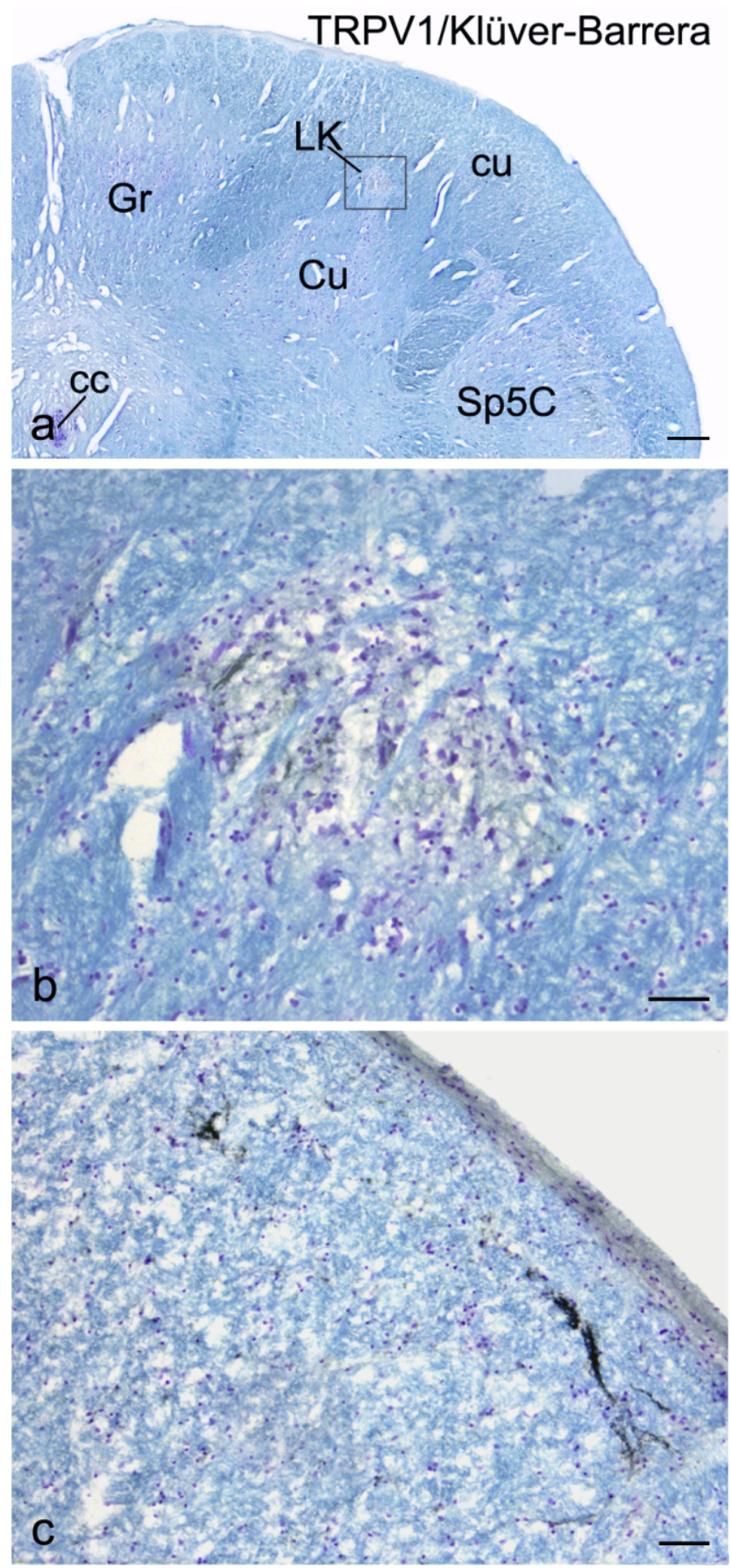

Figure 3. Adult, case 9. Right dorsal quadrant of caudal medulla oblongata immunostained for TRPV1 and counterstained with Klüver-Barrera (a). Locus K (LK) containing TRPV1-LI (box in (a)) is shown in (b) at higher magnification. c: thin fibre bundles in the dorsolateral fasciculus cuneatus (cu). cc, central canal; $\mathrm{Cu}$, cuneate nucleus; Gr, gracile nucleus; Sp5C, caudal spinal trigeminal nucleus. Scale bar: (a) $250 \mu \mathrm{m} ;(\mathbf{b}, \mathbf{c}) 20 \mu \mathrm{m}$. 

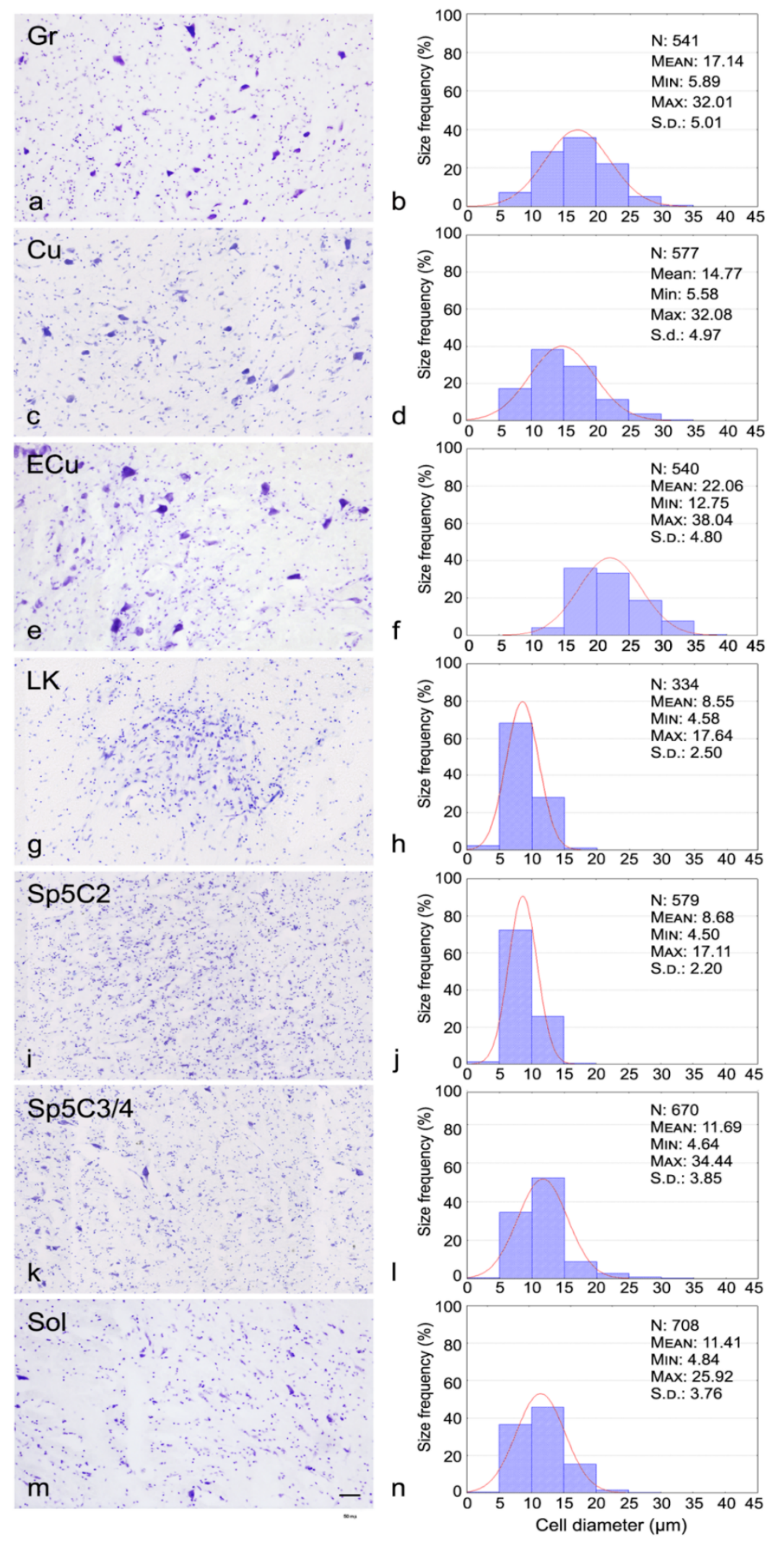

Figure 4. Adult, case 9. Nissl stained gracile nucleus $(\mathrm{Gr})$, cuneate nucleus $(\mathrm{Cu})$, external cuneate nucleus (ECu), Locus K (LK), caudal spinal trigeminal nucleus substantia gelatinosa (Sp5C2) and magnocellular region (Sp5C3/4), solitary nucleus (Sol) and relative size frequency histograms. In histograms, $x$-axis values represent the mean cell diameters expressed in $\mu \mathrm{m}, y$-axis values report the relative percent frequency. Curves superimposed on the histograms represent the theoretical normal distribution. Scale bar: (a, c, e, g, i, k) = (m) $50 \mu \mathrm{m}$. 


\section{Cell density}

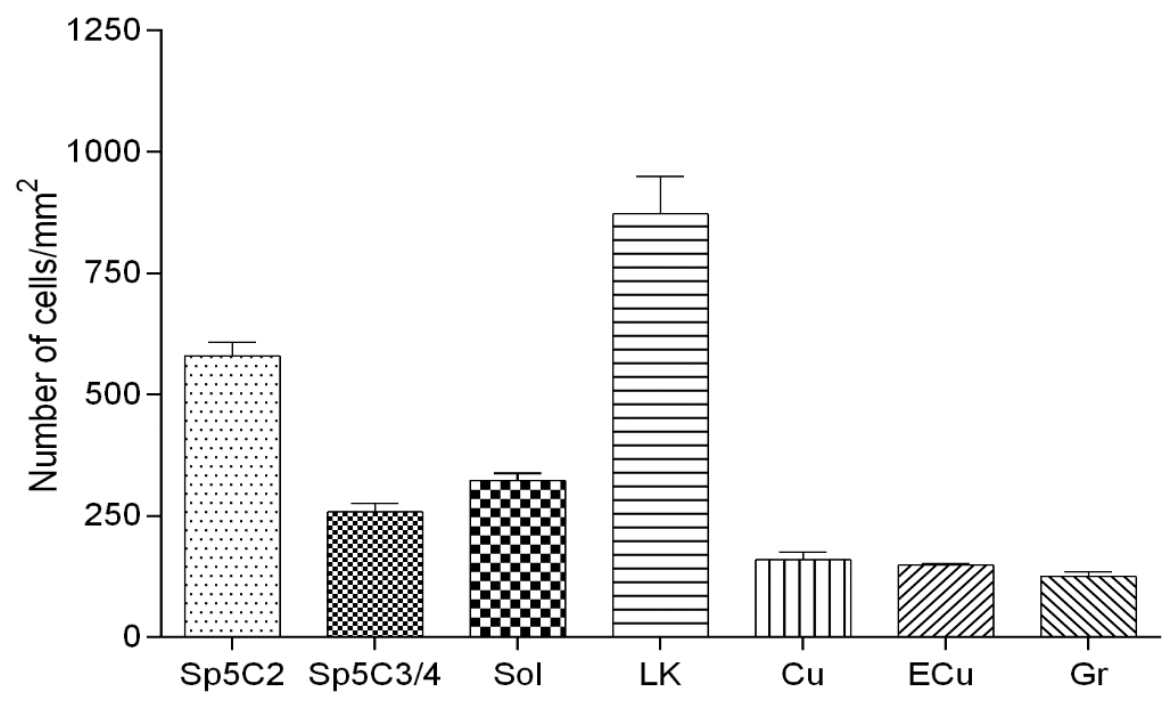

Figure 5. Adult, case 9. Histogram of mean cell density in the Locus $\mathrm{K}(\mathrm{LK})$ as compared to protopathic sensory nuclei and dorsal column nuclei of the human medulla oblongata. Differences in density among the seven regions are statistically significant (see Table 2). Caudal spinal trigeminal nucleus substantia gelatinosa (Sp5C2) and magnocellular region (Sp5C3/4), solitary nucleus (Sol), cuneate nucleus $(\mathrm{Cu})$, external cuneate nucleus $(\mathrm{ECu})$ and gracile nucleus $(\mathrm{Gr})$.

Table 2. $P$-values, calculated by means of one way ANOVA followed by Tukey's post-hoc test, relevant to pair-wise contrasts between mean cell densities of Locus $\mathrm{K}$ (LK) and those of protopathic sensory and dorsal column nuclei in the human medulla oblongata (see histogram in Figure 5). Each $p$-value is adjusted to account for multiple comparison (significance level: 0.05; confidence level: $95 \%$ ). Caudal spinal trigeminal nucleus substantia gelatinosa (Sp5C2) and magnocellular region (Sp5C3/4), solitary nucleus (Sol), cuneate nucleus $(\mathrm{Cu})$, external cuneate nucleus $(\mathrm{ECu})$ and gracile nucleus $(\mathrm{Gr})$.

\begin{tabular}{ccc}
\hline Nuclei & Summary & Adjusted $p$-Value \\
\hline Sp5C3/4 vs. Sol & $*$ & 0.0267 \\
Sp5C3/4 vs. LK & $* *$ & 0.0033 \\
Sp5C2 vs. LK & $* * * *$ & $<0.0001$ \\
Sp5C2 vs. Cu & ns & 0.5456 \\
Sp5C2 vs. ECu & $* * * *$ & $<0.0001$ \\
Sp5C2 vs. Gr & ns & 0.1186 \\
Sp5C3/4 vs. Cu & $* * * *$ & $<0.0001$ \\
Sp5C3/4 vs. ECu & $* * * *$ & $<0.0001$ \\
Sp5C3/4 vs. Gr & $* * * *$ & $<0.0001$ \\
Sol vs. LK & $* * * *$ & $<0.0001$ \\
Sol vs. Cu & $* * * *$ & $<0.0001$ \\
Sol vs. ECu & $* * * *$ & $<0.0001$ \\
Sol vs. Gr & $* * * *$ & $<0.0001$ \\
LK vs. Cu & $* * * *$ & $<0.0001$ \\
LK vs. ECu & $* * * *$ & $<0.0001$ \\
LK vs. Gr & $* * * *$ & $<0.0001$ \\
Cu vs. ECu & ns & 0.9998 \\
Cu vs. Gr & ns & 0.9203 \\
ECu vs. Gr & ns & 0.9771 \\
\hline
\end{tabular}

${ }^{*}, p<0.05 ;{ }^{* *}, p<0.005,{ }^{* * * *}, p<0.0001 ; \mathrm{ns}$, not significant. 


\section{Discussion}

The results obtained provide evidence for the presence of TRPV1-LI, in the form of a network of nerve fibres and terminals, within a set of distinct subnuclear areas located in the territory of the human cuneate nucleus, which we designate as Locus Kalaris or, briefly, Locus K. In a previous study, we provided a three-dimensional reconstruction of those areas [92], showing that the Locus K spans longitudinally from the pyramidal decussation to the obex level, first appearing caudally at the level of the cuneate nucleus caudal pole, and being located along the dorsal border of the cuneate nucleus. Similarly to several other markers, such as neuropeptides and molecules indicative of trophism and neuroplasticity [70,71,92-97], TRPV1-LI is detectable in the Locus $\mathrm{K}$ throughout life, from fetal to adult age. The present study also provides the first description of the morphometric features of the Locus $\mathrm{K}$ and a comparative analysis between Locus $\mathrm{K}$ and a number of the human medulla oblongata sensory nuclei. Among them, the mean cell size shows the lowest values in the Locus $\mathrm{K}$ and in the spinal trigeminal nucleus substantia gelatinosa, is somewhat higher in the spinal trigeminal nucleus magnocellular part and solitary nucleus, and is by far larger in the cuneate, gracile and external cuneate nuclei. A similar, though reversed, trend among the same nuclei is maintained with regard to the mean cell density, which shows the highest value in the Locus $\mathrm{K}$ followed by the spinal trigeminal nucleus substantia gelatinosa, whereas it lessens in the spinal trigeminal nucleus magnocellular part and solitary nucleus, and is greatly reduced in the cuneate, external cuneate and gracile nuclei. Thus, the concurrent immunohistochemical labelling for TRPV1 and the neuropeptides CGRP and SP (this study), which in turn are codistributed with several other markers [92], and the outcome of the cytoand myeloarchitectural analysis, display the remarkable similarity in the neurochemical and structural arrangement between the Locus $\mathrm{K}$ and the protopathic sensory nuclei of the human medulla oblongata. Moreover, the pattern of immunolabeling and relative distribution of TRPV1-, CGRP- and SP-LI uphold the possibility that the Locus $\mathrm{K}$ is structurally organized in a laminar pattern, likewise the spinal trigeminal nucleus substantia gelatinosa. All of these observations induce consideration of a role in protopathic sensory neurotransmission for the Locus $\mathrm{K}$ and a functional involvement of TRPV1 in it, similar to that proposed in the spinal dorsal horn and, more generally, in the protopathic sensory nuclei. Ample evidence on the neurochemical anatomy of the somatosensory system in different animal species, including man, shows that immunoreactivity to several neuropeptides is concentrated in the superficial laminae of the spinal dorsal horn, in the caudal spinal trigeminal nucleus substantia gelatinosa, and in the solitary nucleus, being generally scarce to absent in the dorsal column nuclei [92] (and references therein), [100,101]. In a similar way, at a central level, the majority of TRPV1-containing structures occur in the superficial laminae of the rat spinal cord dorsal horn [22,102-105], in the rat [106] and human trigeminal substantia gelatinosa [27], and have a recognized role in transduction and transmission of noxious stimuli. In these territories, TRPV1 has been localized to unmyelinated (C) or thinly myelinated (Adelta) primary sensory afferents $[1,11,14,102,106]$ that terminate mostly in lamina I and the inner part of lamina II of the rat spinal cord dorsal horn [102,103]. We showed a similar distribution in the human spinal trigeminal nucleus substantia gelatinosa [30]. However, postsynaptic TRPV1 has also been reported in the rodent superficial dorsal horn [103,107-109]. Moreover, together with that in somatic pain perception, TRPV1 appears to play an important role in visceral pain. In fact, at L4-S1 levels of the spinal cord dorsal horn [104,110] and sacral dorsal commissural nucleus [111], TRPV1 expression has been associated with visceral afferents innervating the urinary bladder and other pelvic organs, and TRPV1-bearing terminals have been shown in the solitary nucleus [112,113].

The existence of a region with the neurochemical and structural characteristics as the Locus $\mathrm{K}$ in the territory of the dorsal column nuclei, as well as the occurrence of TRPV1-LI in it, may sound in marked contrast with the classical functional role of those nuclei, which is epicritic sensibility. However, in keeping with a role in pain and protopathic perception, the dorsal columns, largely composed of thick myelinated fibres involved in the transmission of fine touch, vibratory sense and proprioception, also include a large proportion of thin and unmyelinated fibres [114-116], which may reach up to $25 \%$ in the human sacral spinal cord [117]. In the rat, these fibres have been identified as primary afferents 
and many of them are immunoreactive to CGRP and SP [117-121]. Additionally, nociceptive second order sensory fibres run in the dorsal column, composing the post-synaptic dorsal column (PSDC) pathway. The latter originates from neurons located in the central area of the spinal cord [122-124] and includes neuropeptidergic fibres [125]. The PSDC pathway carries visceral nociceptive information and clinical reports show that its surgical interruption effectively relieves intractable visceral pain in cancer patients $[124,126,127]$. Thus, on the one hand, the main involvement in sensory neurotransmission for TRPV1 and several neuropeptides, namely CGRP and SP, remains related to the protopathic sensory perception. On the other hand, the possibility that these molecules play a role in the epicritic sensibility classically attributed to the dorsal column nuclei may also be taken into account. In fact, at both peripheral and central level, TRPV1 may also contribute to mechanotransmission, especially after injury [108,128-131], and TRPV1-immunostaining has been detected in laminae III-V of the spinal cord dorsal horn, receiving, among others, primary afferents involved in proprioception [104]. Moreover, TRPV1- [132] and CGRP-positive fibres [128] have been shown to innervate light touch mechanoreceptor Meissner's corpuscles in monkey and rat, respectively, and SP-positive fibres also occur in human and rat Meissner's corpuscles and other mechanoreceptors [133-135]. We did not detect TRPV1-positive cell bodies in the LK. However, besides the likely prospect that the TRPV1-like immunoreactive fibres of the LK belong to neurons composing a sensory pathway, the possibility that, at least in part, they represent processes of local neurons or glial cells can not be ruled out, as shown in the rat spinal cord, with a role for the receptor in the control of pain transmission and onset of neuropathic pain disfunctions, such as hyperalgesia and allodynia $[22,107,109]$. Finally, the possibility should also be considered that the TRPV1-like immunoreactive fibres in the LK belong, at least in part, to descending projections. In fact, experimental evidence underlines the role of supraspinal TRPV1 in pain modulation, the rostral-ventrolateral medulla (RVM), periaqueductal grey (PAG), amygdala, solitary tract nucleus, locus coeruleus, somatosensory and anterior cingulated cortex, and insula being the territories most involved in this functional meaning [15,136-142]. Although the knowledge of the TRPV1 role in most of these systems is still incomplete, the TRPV1-mediated activation of the PAG-RVM antinociceptive pain pathway has drawn attention as a possible pharmacological target for some types of intractable pain [142].

At the present time, the possible functional involvement of the Locus $\mathrm{K}$ remains a matter of speculation. The localization pattern of TRPV1-, CGRP- and SP-LI in it shows that the elements containing the three markers do not overlap perfectly. This agrees with our findings on the substantia gelatinosa of the spinal trigeminal nucleus [30] and suggests that, especially in the deep part of the Locus $\mathrm{K}$, the TRPV1-LI may reside in non peptidergic $[13,14]$ and perhaps in non presynaptic $[102,143]$ elements.

In conclusion, the Locus K is still a "Nucleus in Search of a Function". However, on a positive note, TRPV1 must be considered one of the Characters playing in it.

Author Contributions: Conceptualization, M.D.F. and M.Q.; Formal analysis, M.P.S.; Funding acquisition, M.D.F., M.P.S. and M.Q.; Investigation, M.D.F., M.P.S., M.B., L.P. and M.Q.; Project administration, M.D.F. and M.Q.; Resources, R.D. and A.C.; Validation, M.D.F., M.P.S., M.B. and M.Q.; Visualization, M.D.F., M.P.S., M.B. and M.Q.; Writing-Original draft, M.D.F. and M.Q.; Writing-Review and editing, M.D.F. and M.Q.

Funding: The study was supported by grants from the Regione Autonoma della Sardegna (P.O.R. F.S.E. 2007-2013) and the University of Cagliari (Progetti di Ricerca di Interesse Dipartimentale, PRID 2015; Fondo Integrativo per la Ricerca, FIR 2016, 2017).

Conflicts of Interest: The authors declare no conflict of interest. The founding sponsors had no role in the design of the study; in the collection, analyses, or interpretation of data; in the writing of the manuscript, and in the decision to publish the results.

\section{References}

1. Caterina, M.J.; Schumacher, M.A.; Tominaga, M.; Rosen, T.A.; Levine, J.D.; Julius, D. The capsaicin receptor: A heat-activated ION channel in the pain pathway. Nature 1997, 389, 816-824. [CrossRef] [PubMed]

2. Szallasi, A.; Cortright, D.N.; Blum, C.A.; Eid, S.R. The vanilloid receptor TRPV1: 10 years from channel cloning to antagonist proof-of-concept. Nat. Rev. Drug Discov. 2007, 6, 357-372. [CrossRef] [PubMed] 
3. Gao, Y.; Cao, E.; Julius, D.; Cheng, Y. TRPV1 structures in nanodiscs reveal mechanisms of ligand and lipid action. Nature 2016, 534, 347-351. [CrossRef] [PubMed]

4. Carnevale, V.; Rohacs, T. TRPV1: A Target for Rational Drug Design. Pharmaceuticals 2016, 9, 52. [CrossRef] [PubMed]

5. Kanai, Y.; Nakazato, E.; Fujiuchi, A.; Hara, T.; Imai, A. Involvement of an increased spinal TRPV1 sensitization through its up-regulation in mechanical allodynia of CCI rats. Neuropharmacology 2005, 49, 977-984. [CrossRef] [PubMed]

6. Basso, L.; Altier, C. Transient Receptor Potential Channels in neuropathic pain. Curr. Opin. Pharmacol. 2017, 32, 9-15. [CrossRef] [PubMed]

7. Wang, C.; Gu, L.; Ruan, Y.; Gegen, T.; Yu, L.; Zhu, C.; Yang, Y.; Zhou, Y.; Yu, G.; Tang, Z. Pirt together with TRPV1 is involved in the regulation of neuropathic pain. Neural Plast. 2018, 2018, 4861491. [CrossRef] [PubMed]

8. Szallasi, A.; Blumberg, P.M. Vanilloid (capsaicin) receptors and mechanisms. Pharmacol. Rev. 1999, 51, 159-212. [PubMed]

9. Hwang, S.W.; Cho, H.; Kwak, J.; Lee, S.Y.; Kang, C.J.; Kang, C.J.; Jung, J.; Cho, S.; Min, K.H.; Suh, Y.G.; et al. Direct activation of capsaicin receptors by products of lipoxygenases: Endogenous capsaicin-like substances. Proc. Natl. Acad. Sci. USA 2000, 97, 6155-6160. [CrossRef] [PubMed]

10. Bölcskei, K.; Helyes, Z.; Szabó, A.; Sándor, K.; Elekes, K.; Németh, J. Investigation of the role of TRPV1 receptors in acute and chronic nociceptive processes using gene-deficient mice. Pain 2005, 117, 368-376. [CrossRef] [PubMed]

11. Holzer, P. The pharmacological challenge to tame the transient receptor potential vanilloid-1 (TRPV1) nocisensor. Br. J. Pharmacol. 2008, 155, 1145-1162. [CrossRef] [PubMed]

12. Helliwell, R.J.; McLatchie, L.M.; Clarke, M.; Winter, J.; Bevan, S.; McIntyre, P. Capsaicin sensitivity is associated with the expression of the vanilloid (capsaicin) receptor (VR1) mRNA in adult rat sensory ganglia. Neurosci. Lett. 1998, 250, 177-180. [CrossRef]

13. Tominaga, M.; Caterina, M.J.; Malmberg, A.B.; Rosen, T.A.; Gilbert, H.; Skinner, K.; Raumann, B.E.; Basbaum, A.I.; Julius, D. The cloned capsaicin receptor integrates multiple pain-producing stimuli. Neuron 1998, 21, 531-543. [CrossRef]

14. Michael, G.J.; Priestley, J.V. Differential expression of the mRNA for the vanilloid receptor subtype 1 in cells of the adult rat dorsal root and nodose ganglia and its downregulation by axotomy. J. Neurosci. 1999, 19, 1844-1854. [CrossRef] [PubMed]

15. Mezey, E.; Tóth, Z.E.; Cortright, D.N.; Arzubi, M.K.; Krause, J.E.; Elde, R.; Guo, A.; Blumberg, P.M.; Szallasi, A. Distribution of mRNA for vanilloid receptor subtype 1 (VR1), and VR1-like immunoreactivity, in the central nervous system of the rat and human. Proc. Natl. Acad. Sci. USA 2000, 97, 3655-3660. [CrossRef] [PubMed]

16. Matsumoto, I.; Emori, Y.; Ninomiya, Y.; Abe, K. A comparative study of three cranial sensory ganglia projecting into the oral cavity: In situ hybridization analyses of neurotrophin receptors and thermosensitive cation channels. Mol. Brain Res. 2001, 93, 105-112. [CrossRef]

17. Ichikawa, H.; Fukunaga, T.; Jin, H.W.; Fujita, M.; Takano-Yamamoto, T.; Sugimoto, T. VR1-, VRL-1- and P2X3 receptor-immunoreactive innervation of the rat temporomandibular joint. Brain Res. 2004, 1008, 131-136. [CrossRef] [PubMed]

18. Ichikawa, H.; Sugimoto, T. The co-expression of VR1 and VRL-1 in the rat vagal sensory ganglia. Brain Res. 2003, 980, 293-296. [CrossRef]

19. Dinh, Q.T.; Groneberg, D.A.; Peiser, C.; Springer, J.; Joachim, R.A.; Arck, P.C.; Klapp, B.F.; Fischer, A. Nerve growth factor-induced substance $\mathrm{P}$ in capsaicin-insensitive vagal neurons innervating the lower mouse airway. Clin. Exp. Allergy 2004, 34, 1474-1479. [CrossRef] [PubMed]

20. Damann, N.; Rothermel, M.; Klupp, B.G.; Mettenleiter, T.C.; Hatt, H.; Wetzel, C.H. Chemosensory properties of murine nasal and cutaneous trigeminal neurons identified by viral tracing. BMC Neurosci. 2006, 7, 46. [CrossRef] [PubMed]

21. Bevan, S.; Quallo, T.; Andersson, D.A. TRPV1. In Handbook of Experimental Pharmacology; Springer: Berlin/Heidelberg, Germany, 2014; Volume 222, pp. 207-245. 
22. Quartu, M.; Carozzi, V.A.; Dorsey, S.G.; Serra, M.P.; Poddighe, L.; Picci, C.R.; Boi, M.A.; Melis, T.I.; Del Fiacco, M.; Meregalli, C.R.; et al. Bortezomib treatment produces nocifensive behavior and changes in the expression of TRPV1, CGRP, and substance P in the rat DRG, spinal cord, and sciatic nerve. BioMed Res. Int. 2014, 180428. [CrossRef] [PubMed]

23. Cortright, D.N.; Crandall, M.; Sanchez, J.F.; Zou, T.; Krause, J.E.; White, G. The tissue distribution and functional characterization of human VR1. Biochem. Biophys. Res. Commun. 2001, 281, 1183-1189. [CrossRef] [PubMed]

24. Holzer, P. TRPV1 and the gut: From a tasty receptor for a painful vanilloid to a key player in hyperalgesia. Eur. J. Pharmacol. 2004, 500, 231-241. [CrossRef] [PubMed]

25. Morgan, C.R.; Rodd, H.D.; Clayton, N.; Davis, J.B.; Boissonade, F.M. Vanilloid receptor 1 expression in human tooth pulp in relation to caries and pain. J. Orofac. Pain 2005, 19, 248-260. [PubMed]

26. Lauria, G.; Morbin, M.; Lombardi, R.; Capobianco, R.; Camozzi, F.; Pareyson, D.; Manconi, M.; Geppetti, P. Expression of capsaicin receptor immunoreactivity in human peripheral nervous system and in painful neuropathies. J. Peripher. Nerv. Syst. 2006, 11, 262-271. [CrossRef] [PubMed]

27. Facer, P.; Smith, G.D.; Benham, C.D.; Chessell, I.P.; Bountra, C.; Sinisi, M.; Birch, R.; Anand, P. Differential expression of the capsaicin receptor TRPV1 and related novel receptors TRPV3, TRPV4 and TRPM8 in normal human tissues and changes in traumatic and diabetic neuropathy. BMC Neurol. 2007, 7, 11. [CrossRef] [PubMed]

28. Anand, U.; Otto, W.R.; Bountra, C.; Chessell, I.; Sinisi, M.; Birch, R.; Anand, P. Cytosine arabinoside affects the heat and capsaicin receptor TRPV1 localisation and sensitivity in human sensory neurons. J. Neurooncol. 2008, 89, 1-7. [CrossRef] [PubMed]

29. Hou, M.; Uddman, R.; Tajti, J.; Kanje, M.; Edvinsson, L. Capsaicin receptor immunoreactivity in the human trigeminal ganglion. Neurosci. Lett. 2002, 330, 223-226. [CrossRef]

30. Quartu, M.; Serra, M.P.; Boi, M.; Poddighe, L.; Picci, C.; Demontis, R.; Del Fiacco, M. TRPV1 receptor in the human trigeminal ganglion and spinal nucleus: Immunohistochemical localization and comparison with the neuropeptides CGRP and SP. J. Anat. 2016, 229, 755-767. [CrossRef] [PubMed]

31. Yilmaz, Z.; Renton, T.; Yiangou, Y.; Zakrzewska, J.; Chessell, I.P.; Bountra, C.; Anand, P. Burning mouth syndrome as a trigeminal small fibre neuropathy: Increased heat and capsaicin receptor TRPV1 in nerve fibres correlates with pain score. J. Clin. Neurosci. 2007, 14, 864-871. [CrossRef] [PubMed]

32. Shinoda, M.; Takeda, M.; Honda, K.; Maruno, M.; Katagiri, A.; Satoh-Kuriwada, S.; Shoji, N.; Tsuchiya, M.; Iwata, K. Involvement of peripheral artemin signaling in tongue pain: Possible mechanism in burning mouth syndrome. Pain 2015, 156, 2528-2537. [CrossRef] [PubMed]

33. Del Fiacco, M.; Quartu, M.; Boi, M.; Serra, M.P.; Melis, T.; Boccaletti, R.; Shevel, E.; Cianchetti, C. TRPV1, CGRP and SP in scalp arteries of patients suffering from chronic migraine. J. Neurol. Neurosurg. Psychiatry 2015, 86, 393-397. [CrossRef] [PubMed]

34. Trevisani, M.; Smart, D.; Gunthorpe, M.J.; Tognetto, M.; Barbieri, M.; Campi, B.; Amadesi, S.; Gray, J.; Jerman, J.C.; Brough, S.J.; et al. Ethanol elicits and potentiates nociceptor responses via the vanilloid receptor-1. Nat. Neurosci. 2002, 5, 546-551. [CrossRef] [PubMed]

35. Grant, A.D.; Gerard, N.P.; Brain, S.D. Evidence of a role for NK1 and CGRP receptors in mediating neurogenic vasodilatation in the mouse ear. Br. J. Pharmacol. 2002, 135, 356-362. [CrossRef] [PubMed]

36. Chizh, B.A.; O’Donnell, M.B.; Napolitano, A.; Wang, J.; Brooke, A.C.; Aylott, M.C.; Bullman, J.N.; Gray, E.J.; Lai, R.Y.; Williams, P.M.; et al. The effects of the TRPV1 antagonist SB-705498 on TRPV1 receptor-mediated activity and inflammatory hyperalgesia in humans. Pain 2007, 132, 132-141. [CrossRef] [PubMed]

37. Starr, A.; Graepel, R.; Keeble, J.; Schmidhuber, S.; Clark, N.; Grant, A.; Shah, A.M.; Brain, S.D. A reactive oxygen species-mediated component in neurogenic vasodilatation. Cardiovasc. Res. 2008, 78, 139-147. [CrossRef] [PubMed]

38. Park, C.K.; Kim, M.S.; Fang, Z.; Li, H.Y.; Jung, S.J.; Choi, S.Y.; Lee, S.J.; Park, K.; Kim, J.S.; Oh, S.B. Functional expression of thermo-transient receptor potential channels in dental primary afferent neurons: Implication for tooth pain. J. Biol. Chem. 2006, 281, 17304-17311. [CrossRef] [PubMed]

39. Akbar, A.; Yiangou, Y.; Facer, P.; Walters, J.R.; Anand, P.; Ghosh, S. Increased capsaicin receptor TRPV1-expressing sensory fibres in irritable bowel syndrome and their correlation with abdominal pain. Gut 2008, 57, 923-929. [CrossRef] [PubMed] 
40. Holzer, P. Transient receptor potential (TRP) channels as drug targets for diseases of the digestive system. Pharmacol. Ther. 2011, 131, 142-170. [CrossRef] [PubMed]

41. Holzer, P.; Izzo, A.A. The pharmacology of TRP channels. Br. J. Pharmacol. 2014, 171, 2469-2473. [CrossRef] [PubMed]

42. Chung, M.-K.; Lee, J.; Duraes, G.; Ro, J.Y. Lipopolysaccharide-induced pulpitis up-regulates TRPV1 in trigeminal ganglia. J. Dent. Res. 2011, 90, 1103-1107. [CrossRef] [PubMed]

43. Brandt, M.R.; Beyer, C.E.; Stahl, S.M. TRPV1 Antagonists and Chronic Pain: Beyond Thermal Perception. Pharmaceuticals 2012, 5, 114-132. [CrossRef] [PubMed]

44. Sikandar, S.; Dickenson, A.H. Visceral pain: The ins and outs, the ups and downs. Curr. Opin. Support. Palliat. Care 2012, 6, 17-26. [CrossRef] [PubMed]

45. Kondo, E.; Jinnouchi, O.; Nakano, S.; Ohnishi, H.; Kawata, I.; Okamoto, H.; Takeda, N. Aural stimulation with capsaicin ointment improved swallowing function in elderly patients with dysphagia: A randomized, placebo-controlled, double-blind, comparative study. Clin. Interv. Aging 2017, 12, 1921-1928. [CrossRef] [PubMed]

46. Urano, H.; Ara, T.; Fujinami, Y.; Hiraoka, B.Y. Aberrant TRPV1 expression in heat hyperalgesia associated with trigeminal neuropathic pain. Int. J. Med. Sci. 2012, 9, 690-697. [CrossRef] [PubMed]

47. Zakir, H.M.; Mostafeezur, R.M.; Suzuki, A.; Hitomi, S.; Suzuki, I.; Maeda, T.; Seo, K.; Yamada, Y.; Yamamura, K.; Lev, S.; et al. Expression of TRPV1 channels after nerve injury provides an essential delivery tool for neuropathic pain attenuation. PLoS ONE 2012, 7, e44023. [CrossRef] [PubMed]

48. Gazerani, P.; Pedersen, N.S.; Staahl, C.; Drewes, A.M.; Arendt-Nielsen, L. Subcutaneous Botulinum toxin type A reduces capsaicin-induced trigeminal pain and vasomotor reactions in human skin. Pain 2009, 141, 60-69. [CrossRef] [PubMed]

49. Aykanat, V.; Gentgall, M.; Briggs, N.; Williams, D.; Yap, S.; Rolan, P. Intradermal capsaicin as a neuropathic pain model in patients with unilateral sciatica. Br. J. Clin. Pharmacol. 2012, 73, 37-45. [CrossRef] [PubMed]

50. Silberberg, A.; Moeller-Bertram, T.; Wallace, M.S. A randomized, double-blind, crossover study to evaluate the depth response relationship of intradermal capsaicin-induced pain and hyperalgesia in healthy adult volunteers. Pain Med. 2015, 16, 745-752. [CrossRef] [PubMed]

51. Fehrenbacher, J.C.; Sun, X.X.; Locke, E.E.; Henry, M.A.; Hargreaves, K.M. Capsaicin-evoked CGRP release from human dental pulp: A model system for the study of peripheral neuropeptide secretion in normal healthy tissue. Pain 2009, 144, 253-261. [CrossRef] [PubMed]

52. Burns, L.E.; Ramsey, A.A.; Emrick, J.J.; Janal, M.N.; Gibbs, J.L. Variability in Capsaicin-stimulated Calcitonin Gene-related Peptide Release from Human Dental Pulp. J. Endod. 2016, 42, 542-546. [CrossRef] [PubMed]

53. Witting, N.; Svensson, P.; Gottrup, H.; Arendt-Nielsen, L.; Jensen, T.S. Intramuscular and intradermal injection of capsaicin: A comparison of local and referred pain. Pain 2000, 84, 407-412. [CrossRef]

54. Arendt-Nielsen, L.; Yarnitsky, D. Experimental and clinical applications of quantitative sensory tsting applied to skin, muscles and viscera. J. Pain 2009, 10, 556-572. [CrossRef] [PubMed]

55. Sohn, M.K.; Graven-Nielsen, T.; Arendt-Nielsen, L.; Svensson, P. Inhibition of motor unit firing during experimental muscle pain in humans. Muscle Nerv. 2000, 23, 1219-1226. [CrossRef]

56. O'Neill, J.; Brock, C.; Olesen, A.E.; Andresen, T.; Nilsson, M.; Dickenson, A.H. Unravelling the mystery of capsaicin: A tool to understand and treat pain. Pharmacol. Rev. 2012, 64, 939-971. [CrossRef] [PubMed]

57. Pompeiano, O.; Brodal, A. Spinovestibular fibers in the cat; an experimental study. J. Comp. Neurol. 1957, 108, 353-381. [CrossRef] [PubMed]

58. Galindo, A.; Krnjević, K.; Schwartz, S. Micro-iontophoretic studies on neurones in the cuneate nucleus. J. Physiol. 1967, 192, 359-377. [CrossRef] [PubMed]

59. Roberts, P.J. The release of amino acids with proposed neurotransmitter function from the cuneate and gracile nuclei of the rat in vivo. Brain Res. 1974, 67, 419-428. [CrossRef]

60. Rustioni, A.; Schmechel, D.E.; Cheema, S.; Fitzpatrick, D. Glutamic acid decarboxylase-containing neurons in the dorsal column nuclei of the cat. Somatosens. Res. 1984, 1, 329-357. [CrossRef] [PubMed]

61. Westman, J. Light and electron microscopical studies of the GABA innervation of the dorsal column nuclei and the lateral cervical nucleus in the primate species Macaca fascicularis and Papio anubis. Upsala J. Med. Sci. 1989, 94, 255-270. [CrossRef] [PubMed]

62. De Biasi, S.; Rustioni, A. Ultrastructural immunocytochemical localization of excitatory amino acids in the somatosensory system. J. Histochem. Cytochem. 1990, 38, 1745-1754. [CrossRef] [PubMed] 
63. Heino, R.; Westman, J. Quantitative analysis of the feline dorsal column nuclei and their GABAergic and non-GABAergic neurons. Anat. Embryol. 1991, 184, 181-193. [CrossRef] [PubMed]

64. De Biasi, S.; Vitellaro-Zuccarello, L.; Bernardi, P.; Valtschanoff, J.G.; Weinberg, R.J. Ultrastructural and immunocytochemical characterization of primary afferent terminals in the rat cuneate nucleus. J. Comp. Neurol. 1994, 347, 275-287. [CrossRef] [PubMed]

65. Popratiloff, A.; Valtschanoff, J.G.; Rustioni, A.; Weinberg, R.J. Colocalization of GABA and glycine in the rat dorsal column nuclei. Brain Res. 1996, 706, 308-312. [CrossRef]

66. Lue, J.H.; Chen, S.H.; Shieh, J.Y.; Wen, C.Y. Afferent synaptic contacts on glycine-immunoreactive neurons in the rat cuneate nucleus. Synapse 2001, 41, 139-149. [CrossRef] [PubMed]

67. Henderson, Z; Sherriff, F.E. Distribution of choline acetyltransferase immunoreactive axons and terminals in the rat and ferret brainstem. J. Comp. Neurol. 1991, 314, 147-163. [CrossRef] [PubMed]

68. Blomqvist, A.; Broman, J. Serotoninergic innervation of the dorsal column nuclei and its relation to cytoarchitectonic subdivisions: An immunohistochemical study in cats and monkeys (Aotus trivirgatus). J. Comp. Neurol. 1993, 327, 584-596. [CrossRef] [PubMed]

69. Maqbool, A.; Batten, T.F.; Berry, P.A.; McWilliam, P.N. Distribution of dopamine-containing neurons and fibres in the feline medulla oblongata: A comparative study using catecholamine-synthesizing enzyme and dopamine immunohistochemistry. Neuroscience 1993, 53, 717-733. [CrossRef]

70. Del Fiacco, M.; Dessi, M.L.; Atzori, M.G.; Levanti, M.C. Substance P in the human brainstem. Preliminary results of its immunohistochemical localization. Brain Res. 1983, 264, 142-147. [CrossRef]

71. Del Fiacco, M.; Dessì, M.L.; Levanti, M.C. Topographical localization of substance P in the human post-mortem brainstem. An immunohistochemical study in the newborn and adult tissue. Neuroscience 1984, 12, 591-611. [CrossRef]

72. Chigr, F.; Najimi, M.; Leduque, P.; Charnay, Y.; Jordan, D.; Chayvialle, J.A.; Tohyama, M.; Kopp, N. Anatomical distribution of somatostatin immunoreactivity in the infant brainstem. Neuroscience 1989, 29, 615-628. [CrossRef]

73. Unger, J.W.; Lange, W. Immunohistochemical mapping of neurophysins and calcitonin gene-related peptide in the human brainstem and cervical spinal cord. J. Chem. Neuroanat. 1991, 4, 299-309. [CrossRef]

74. Coveñas, R.; Martin, F.; Belda, M.; Smith, V.; Salinas, P.; Rivada, E.; Gonzalez-Baron, S. Mapping of neurokinin-like immunoreactivity in the human brainstem. BMC Neurosci. 2003, 4, 3. [CrossRef]

75. Coveñas, R.; Martín, F.; Salinas, P.; Rivada, E.; Smith, V.; Aguilar, L.A.; Díaz-Cabiale, Z.; Narváez, J.A.; Tramu, G. An immunocytochemical mapping of methionine-enkephalin-Arg(6)-Gly(7)-Leu(8) in the human brainstem. Neuroscience 2004, 128, 843-859. [CrossRef] [PubMed]

76. Simantov, R.; Kuhar, M.J.; Uhl, G.R.; Snyder, S.H. Opioid peptide enkephalin: Immunohistochemical mapping in rat central nervous system. Proc. Natl. Acad. Sci. USA 1977, 74, 2167-2171. [CrossRef] [PubMed]

77. Cuello, A.C.; Kanazawa, I. The distribution of substance P immunoreactive fibers in the rat central nervous system. J. Comp. Neurol. 1978, 178, 129-156. [CrossRef] [PubMed]

78. Ljungdahl, A.; Hökfelt, T.; Nilsson, G. Distribution of substance P-like immunoreactivity in the central nervous system of the rat-I. Cell bodies and nerve terminals. Neuroscience 1978, 3, 861-943. [CrossRef]

79. Haber, S.; Elde, R. The distribution of enkephalin immunoreactive fibers and terminals in the monkey central nervous system: An immunohistochemical study. Neuroscience 1982, 7, 1049-1095. [CrossRef]

80. Conrath-Verrier, M.; Dietl, M.; Arluison, M.; Cesselin, F.; Bourgoin, S.; Hamon, M. Localization of Met-enkephalin-like immunoreactivity within pain-related nuclei of cervical spinal cord, brainstem and midbrain in the cat. Brain Res. Bull. 1983, 11, 587-604. [CrossRef]

81. Johansson, O.; Hökfelt, T.; Elde, R.P. Immunohistochemical distribution of somatostatin-like immunoreactivity in the central nervous system of the adult rat. Neuroscience 1984, 13, 265-339. [CrossRef]

82. Kawai, Y.; Takami, K.; Shiosaka, S.; Emson, P.C.; Hillyard, C.J.; Girgis, S.; MacIntyre, I.; Tohyama, M. Topographic localization of calcitonin gene-related peptide in the rat brain: An immunohistochemical analysis. Neuroscience 1985, 15, 747-763. [CrossRef]

83. Vincent, S.R.; McIntosh, C.H.; Buchan, A.M.; Brown, J.C. Central somatostatin systems revealed with monoclonal antibodies. J. Comp. Neurol. 1985, 238, 169-186. [CrossRef] [PubMed]

84. Skofitsch, G.; Jacobowitz, D.M. Immunohistochemical mapping of galanin-like neurons in the rat central nervous system. Peptides 1985, 6, 509-546. [CrossRef] 
85. Skofitsch, G.; Jacobowitz, D.M. Calcitonin gene-related peptide: Detailed immunohistochemical distribution in the central nervous system. Peptides 1985, 6, 721-745. [CrossRef]

86. Taber-Pierce, E.; Lichentenstein, E.; Feldman, S.C. The somatostatin systems of the guinea-pig brainstem. Neuroscience 1985, 15, 215-235. [CrossRef]

87. Melander, T.; Hökfelt, T.; Rökaeus, A. Distribution of galanin-like immunoreactivity in the rat central nervous system. J. Comp. Neurol. 1986, 248, 475-517. [CrossRef] [PubMed]

88. Kruger, L.; Sternini, C.; Brecha, N.C.; Mantyh, P.W. Distribution of calcitonin gene-related peptide immunoreactivity in relation to the rat central somatosensory projection. J. Comp. Neurol. 1988, 273, 149-162. [CrossRef] [PubMed]

89. Kordower, J.H.; Le, H.K.; Mufson, E.J. Galanin immunoreactivity in the primate central nervous system. J. Comp. Neurol. 1992, 319, 479-500. [CrossRef] [PubMed]

90. Zhang, X.; Meister, B.; Elde, R.; Verge, V.M.; Hökfelt, T. Large calibre primary afferent neurons projecting to the gracile nucleus express neuropeptide $\mathrm{Y}$ after sciatic nerve lesions: An immunohistochemical and in situ hybridization study in rats. Eur. J. Neurosci. 1993, 5, 1510-1519. [CrossRef] [PubMed]

91. Van Rossum, D.; Hanisch, U.K.; Quirion, R. Neuroanatomical localization, pharmacological characterization and functions of CGRP, related peptides and their receptors. Neurosci. Biobehav. Rev. 1997, 21, 649-678. [CrossRef]

92. Del Fiacco, M.; Quartu, M.; Serra, M.P.; Boi, M.; Demontis, R.; Poddighe, L.; Picci, C.; Melis, T. The human cuneate nucleus contains discrete subregions whose neurochemical features match those of the relay nuclei for nociceptive information. Brain Struct. Funct. 2014, 219, 2083-2101. [CrossRef] [PubMed]

93. Del Fiacco, M.; Quartu, M.; Serra, M.P.; Follesa, P.; Lai, M.L.; Bachis, A. Topographical localization of glial cell line-derived neurotrophic factor in the human brain stem: An immunohistochemical study of prenatal, neonatal and adult brains. J. Chem. Neuroanat. 2002, 23, 29-48. [CrossRef]

94. Quartu, M.; Lai, M.L.; Del Fiacco, M. GAP-43 in the spinal trigeminal and dorsal column nuclei of the newborn and adult man: Immunohistochemical distribution and comparison with that of the neuropeptides SP and CGRP. Ital. J. Anat. Embryol. 1995, 100, 205-211. [PubMed]

95. Quartu, M.; Serra, M.P.; Boi, M.; Ferretti, M.T.; Lai, M.L.; Del Fiacco, M. Tissue distribution of Ret, GFRalpha-1, GFRalpha-2 and GFRalpha-3 receptors in the human brainstem at fetal, neonatal and adult age. Brain Res. 2007, 1173, 36-52. [CrossRef] [PubMed]

96. Quartu, M.; Serra, M.P.; Boi, M.; Sestu, N.; Lai, M.L.; Del Fiacco, M. Tissue distribution of neurturin, persephin and artemin in the human brainstem at fetal, neonatal and adult age. Brain Res. 2007, 1143, 102-115. [CrossRef] [PubMed]

97. Quartu, M.; Serra, M.P.; Boi, M.; Ibba, V.; Melis, T.; Del Fiacco, M. Polysialylated-neural cell adhesion molecule (PSA-NCAM) in the human trigeminal ganglion and brainstem at prenatal and adult ages. BMC Neurosci. 2008, 9, 108. [CrossRef] [PubMed]

98. Serra, M.P.; Quartu, M.; Poddighe, L.; Picci, C.; Melis, T.; Del Fiacco, M. Locus K: A novel territory of the human dorsal column nuclei. In Proceedings of the 23th National Congress of Gruppo Italiano per lo $\mathrm{S}$ tudio della Neuromorfologia, Cagliari, Italy, 22-23 November 2013; PAGE Press: Pavia, Italy, 2013; p. 13.

99. Serra, M.P.; Quartu, M.; Boi, M.; Poddighe, L.; Melis, T.; Picci, C.; Del Fiacco, M. Locus K: Cuneate subnuclear regions in human dorsal column nuclei with neurochemical, cyto- and myeloarchitectural features of protopathic sensory nuclei. In Proceedings of the 9th FENS Forum of Neuroscience, Milan, Italy, 5-9 July 2014; Volume 7, p. 2773.

100. Rustioni, A.; Weinberg, R.J. The somatosensory system. In Handbook of Chemical Neuroanatomy, Integrated Systems of the CNS, Part II; Björklund, A., Hökfelt, T., Swanson, L.W., Eds.; Elsevier Science Publishers B.V. (Biomedical Division): Amsterdam, Holland, 1989; Volume 7, pp. 219-321. ISBN 0444812326, 9780444812322.

101. Broman, J. Neurotransmitters in subcortical somatosensory pathways. Anat. Embryol. 1994, 189, $181-214$. [CrossRef] [PubMed]

102. Guo, A.; Vulchanova, L.; Wang, J.; Li, X.; Elde, R. Immunocytochemical localization of the vanilloid receptor 1 (VR1): Relationship to neuropeptides, the P2X3 purinoceptor and IB4 binding sites. Eur. J. Neurosci. 1999, 11, 946-958. [CrossRef] [PubMed]

103. Valtschanoff, J.G.; Rustioni, A.; Guo, A.; Hwang, S.J. Vanilloid receptor VR1 is both presynaptic and postsynaptic in the superficial laminae of the rat dorsal horn. J. Comp. Neurol. 2001, 436, 225-235. [CrossRef] [PubMed] 
104. Hwang, S.J.; Oh, J.M.; Valtschanoff, J.G. Expression of the vanilloid receptor TRPV1 in rat dorsal root ganglion neurons supports different roles of the receptor in visceral and cutaneous afferents. Brain Res. 2005, 1047, 261-266. [CrossRef] [PubMed]

105. Špicarová, D.; Paleček, J. The role of spinal cord vanilloid (TRPV1) receptors in pain modulation. Physiol. Res. 2008, 57 (Suppl. 3), S69-S77. [PubMed]

106. Bae, Y.C.; Oh, J.M.; Hwang, S.J.; Shigenaga, Y.; Valtschanoff, J.G. Expression of vanilloid receptor TRPV1 in the rat trigeminal sensory nuclei. J. Comp. Neurol. 2004, 478, 62-71. [CrossRef] [PubMed]

107. Doly, S.; Fischer, J.; Salio, C.; Conrath, M. The vanilloid receptor-1 is expressed in rat spinal dorsal horn astrocytes. Neurosci. Lett. 2004, 357, 123-126. [CrossRef] [PubMed]

108. Chen, Y.; Willcockson, H.H.; Valtschanoff, J.G. Influence of the vanilloid receptor TRPV1 on the activation of spinal cord glia in mouse models of pain. Exp. Neurol. 2009, 220, 383-390. [CrossRef] [PubMed]

109. Kim, Y.H.; Back, S.K.; Davies, A.J.; Jeong, H.; Jo, H.J.; Chung, G.; Na, H.S.; Bae, Y.C.; Kim, S.J.; Kim, J.S.; et al. TRPV1 in GABAergic interneurons mediates neuropathic mechanical allodynia and disinhibition of the nociceptive circuitry in the spinal cord. Neuron 2012, 74, 640-647. [CrossRef] [PubMed]

110. Hwang, S.J.; Valtschanoff, J.G. Vanilloid receptor VR1-positive afferents are distributed differently at different levels of the rat lumbar spinal cord. Neurosci. Lett. 2003, 349, 41-44. [CrossRef]

111. Yang, K. Postnatal excitability development and innervation by functional transient receptor potential vanilloid 1 (TRPV1) terminals in neurons of the rat spinal sacral dorsal commissural nucleus: An electrophysiological study. Mol. Neurobiol. 2016, 53, 6033-6042. [CrossRef] [PubMed]

112. Mandadi, S.; Roufogalis, B.D. ThermoTRP channels in nociceptors: Taking a lead from capsaicin receptor TRPV1. Curr. Neuropharmacol. 2008, 6, 21-38. [CrossRef] [PubMed]

113. Peters, J.H.; McDougall, S.J.; Fawley, J.A.; Andresen, M.C. TRPV1 marks synaptic segregation of multiple convergent afferents at the rat medial solitary tract nucleus. PLoS ONE 2011, 6, e25015. [CrossRef] [PubMed]

114. Langford, L.A.; Coggeshall, R.E. Unmyelinated axons in the Posterior funiculi. Science 1981, 211, $176-177$. [CrossRef] [PubMed]

115. Chung, K.S.; Coggeshall, R.E. Unmyelinated primary afferent fibers in dorsal funiculi of cat sacral spinal cord. J. Comp. Neurol. 1985, 238, 365-369. [CrossRef] [PubMed]

116. Chung, K.; Langford, L.A.; Coggeshall, R.E. Primary afferent and propriospinal fibers in the rat dorsal and dorsolateral funiculi. J. Comp. Neurol. 1987, 263, 68-75. [CrossRef] [PubMed]

117. McNeill, D.L.; Chung, K.; Carlton, S.M.; Coggeshall, R.E. Calcitonin gene-related peptide immunostained axons provide evidence for fine primary afferent fibers in the dorsal and dorsolateral funiculi of the rat spinal cord. J. Comp. Neurol. 1988, 272, 303-308. [CrossRef] [PubMed]

118. Tamatani, M.; Senba, E.; Tohyama, M. Calcitonin gene-related peptide- and substance P-containing primary afferent fibers in the dorsal column of the rat. Brain Res. 1989, 495, 122-130. [CrossRef]

119. Patterson, J.T.; Coggeshall, R.E.; Lee, W.T.; Chung, K. Long ascending unmyelinated primary afferent axons in the rat dorsal column: Immunohistochemical localizations. Neurosci. Lett. 1990, 108, 6-10. [CrossRef]

120. Noguchi, K.; Kawai, Y.; Fukuoka, T.; Senba, E.; Miki, K. Substance P induced by peripheral nerve injury in primary afferent sensory neurons and its effect on dorsal column nucleus neurons. J. Neurosci. 1995, 15, 7633-7643. [CrossRef] [PubMed]

121. Miki, K.; Fukuoka, T.; Tokunaga, A.; Noguchi, K. Calcitonin gene-related peptide increase in the rat spinal dorsal horn and dorsal column nucleus following peripheral nerve injury: Up-regulation in a subpopulation of primary afferent sensory neurons. Neuroscience 1998, 82, 1243-1252. [CrossRef]

122. Rustioni, A. Spinal neurons project to the dorsal column nuclei of rhesus monkeys. Science 1976, 196, 656-658. [CrossRef]

123. Willis, W.D.; Coggeshall, R.E. Sensory Mechanisms of the Spinal Cord; Kluwer Academic/Plenum Publishers: New York, NY, USA, 2004.

124. Wang, Y.; Mu, X.; Liu, Y.; Zhang, X.; Wu, A.; Yue, Y. NK-1-receptor-mediated lesion of spinal post-synaptic dorsal column neurons might improve intractable visceral pain of cancer origin. Med. Hypotheses 2011, 76, 102-104. [CrossRef] [PubMed]

125. Conti, F.; De Biasi, S.; Giuffrida, R.; Rustioni, A. Substance P containing projections in the dorsal columns of rats and cats. Neuroscience 1990, 34, 607-621. [CrossRef] 
126. Becker, R.; Gatscher, S.; Sure, U.; Bertalanffy, H. The punctate midline myelotomy concept for visceral cancer pain control-case report and review of the literature. Acta Neurochir. Suppl. 2002, 79, 77-78. [CrossRef] [PubMed]

127. Paleček, J. The Role of Dorsal Columns Pathway in Visceral Pain. Physiol. Res. 2004, 53 (Suppl. 1), S125-S130. [PubMed]

128. Pomonis, J.D.; Harrison, J.E.; Mark, L.; Bristol, D.R.; Valenzano, K.J.; Walker, K. N-(4-Tertiarybutylphenyl)-4-(3-cholorphyridin-2-yl)tetrahydropyrazine-1 (2H)-carbox-amide (BCTC), a novel, orally effective vanilloid receptor 1 antagonist with analgesic properties: II. In vivo characterization in rat models of inflammatory and neuropathic pain. J. Pharmacol. Exp. Ther. 2003, 306, 387-393. [CrossRef] [PubMed]

129. Cui, M.; Honore, P.; Zhong, C.; Gauvin, D.; Mikusa, J.; Hernandez, G.; Chandran, P.; Gomtsyan, A.; Brown, B.; Bayburt, E.K.; et al. TRPV1 receptors in the CNS play a key role in broad-spectrum analgesia of TRPV1 antagonists. J. Neurosci. 2006, 26, 9385-9393. [CrossRef] [PubMed]

130. Culshaw, A.J.; Bevan, S.; Christiansen, M.; Copp, P.; Davis, A.; Davis, C.; Dyson, A.; Dziadulewicz, E.K.; Edwards, L.; Eggelte, H.; et al. Identification and biological characterization of 6-aryl-7-isopropylquinazolinones as novel TRPV1 antagonists that are effective in models of chronic pain. J. Med. Chem. 2006, 49, 471-474. [CrossRef] [PubMed]

131. McGaraughty, S.; Chu, K.L.; Brown, B.S.; Zhu, C.Z.; Zhong, C.; Joshi, S.K.; Honore, P.; Faltynek, C.R.; Jarvis, M.F. Contributions of central and peripheral TRPV1 receptors to mechanically evoked and spontaneous firing of spinal neurons in inflamed rats. J. Neurophysiol. 2008, 100, 3158-3166. [CrossRef] [PubMed]

132. Paré, M.; Elde, R.; Mazurkiewicz, J.E.; Smith, A.M.; Rice, F.L. The Meissner corpuscle revised: A multiafferented mechanoreceptor with nociceptor immunochemical properties. J. Neurosci. 2001, 21, 7236-7246. [CrossRef] [PubMed]

133. Ishida-Yamamoto, A.; Senba, E.; Tohyama, M. Calcitonin gene-related peptide- and substance P-immunoreactive nerve fibers in Meissner's corpuscles of rats: An immunohistochemical analysis. Brain Res. 1988, 453, 362-366. [CrossRef]

134. Dalsgaard, C.J.; Jonsson, C.E.; Hökfelt, T.; Cuello, A.C. Localization of substance P-immunoreactive nerve fibers in the human digital skin. Experientia 1983, 39, 1018-1020. [CrossRef] [PubMed]

135. Ide, K.; Yasumasa, S.; Hiromoto, I.; Hironubu, I. Sensory nerve supply in the human subacromial bursa. J. Shoulder Elb. Surg. 1996, 5, 371-382. [CrossRef]

136. Cristino, L.; de Petrocellis, L.; Pryce, G.; Baker, D.; Guglielmotti, V.; Di Marzo, V. Immunohistochemical localization of cannabinoid type 1 and vanilloid transient receptor potential vanilloid type 1 receptors in the mouse brain. Neuroscience 2006, 139, 1405-1415. [CrossRef] [PubMed]

137. Liapi, A.; Wood, J.N. Extensive co-localization and heteromultimer formation of the vanilloid receptor-like protein TRPV2 and the capsaicin receptor TRPV1 in the adult rat cerebral cortex. Eur. J. Neurosci. 2005, 22, 825-834. [CrossRef] [PubMed]

138. Maione, S.; Bisogno, T.; de Novellis, V.; Palazzo, E.; Cristino, L.; Valenti, M.; Petrosino, S.; Guglielmotti, V.; Rossi, F.; Di Marzo, V. Elevation of endocannabinoid levels in the ventrolateral periaqueductal grey through inhibition of fatty acid amide hydrolase affects descending nociceptive pathways via both cannabinoid receptor type 1 and transient receptor potential vanilloid type-1 receptors. J. Pharmacol. Exp. Ther. 2006, 316, 969-982. [CrossRef] [PubMed]

139. Roberts, J.C.; Davis, J.B.; Benham, C.D. $\left[{ }^{3} \mathrm{H}\right]$ Resiniferatoxin autoradiography in the CNS of wild-type and TRPV1 null mice defines TRPV1 (VR-1) protein distribution. Brain Res. 2004, 995, 176-183. [CrossRef] [PubMed]

140. Nagy, I.; Sántha, P.; Jancsó, G.; Urbán, L. The role of the vanilloid (capsaicin) receptor (TRPV1) in physiology and pathology. Eur. J. Pharmacol. 2004, 500, 351-369. [CrossRef] [PubMed]

141. Palazzo, E.; Rossi, F.; Maione, S. Role of TRPV1 receptors in descending modulation of pain. Mol. Cell. Endocrinol. 2008, 286 (Suppl. 1), S79-S83. [CrossRef] [PubMed]

142. Tóth, A.; Boczán, J.; Kedei, N.; Lizanecz, E.; Bagi, Z.; Papp, Z.; Édes, I.; Csiba, L.; Blumberg, P.M. Expression and distribution of vanilloid receptor 1 (TRPV1) in the adult rat brain. Mol. Brain Res. 2005, 135, 162-168. [CrossRef] [PubMed] 
143. Aoki, Y.; Ohtori, S.; Takahashi, K.; Ino, H.; Douya, H.; Ozawa, T.; Saito, T.; Moriya, H. Expression and co-expression of VR1, CGRP, and IB4-binding glycoprotein in dorsal root ganglion neurons in rats: Differences between the disc afferents and the cutaneous afferents. Spine 2005, 30, 1496-1500. [CrossRef] [PubMed]

(c)

(C) 2018 by the authors. Licensee MDPI, Basel, Switzerland. This article is an open access article distributed under the terms and conditions of the Creative Commons Attribution (CC BY) license (http:/ / creativecommons.org/licenses/by/4.0/). 